TAVARES, Vander - The inter-relatedness of emotion, language learning and identity.

Para lá da tarefa: implicar os estudantes na aprendizagem de línguas estrangeiras no ensino superior. Porto: FLUP, 2019, pp. 394-413 DOI: https://doi.org/10.21747/9789898969217/paraa22

\title{
The inter-relatedness of emotion, language learning and identity
}

\author{
Vander Tavares \\ York University, Toronto, Canada \\ vander1@yorku.ca
}

\begin{abstract}
This paper explores the role of emotions and corporeal sensations in the experiences of foreign language learning and identity of one Canadian adult learner of Portuguese. Emotions in second and foreign language learning have become the subject of growing interest since other perspectives other than the cognitive have been included in Second Language Acquisition (SLA) research. Yet, much of the recent literature on the relationship of emotions, foreign language learning, and identity continues to reflect the experiences of English language learners, and has also paid little attention to whether learners develop and include an awareness of and an attention to the contribution of corporeal sensations to their experiences of foreign language learning, and identity enactment in the foreign language. This paper draws on concepts of sociocultural theory and construals-of-the-self to understand the learner's perceptions of her experiences learning Portuguese, and of her identity-related experiences in this language with a focus on emotions. Findings suggest that the learner's conceptualisations of her target identity were imagined and constructed also through corporeal sensations that she experienced and regarded as being characteristic of her target language identities. In addition, a connection between past subjective experiences and the learner's perceptions of foreign language identities was also found. With this understanding, this paper calls for future research to expand on this attention to these emotional aspects that, in addition to linguistic ones, may constitute learners' aspirations and ideas of target language identities.
\end{abstract}

Key-words: identity, foreign language, Portuguese, corporeal sensations, emotions

\section{1 - Introduction}

In the emerging days of second language acquisition (SLA) research as a field of study, second language learning was viewed largely as a primarily cognitive experience (Myles, 2013). A few decades later, some researchers called for a more holistic approach 
TAVARES, Vander - The inter-relatedness of emotion, language learning and identity. Para lá da tarefa: implicar os estudantes na aprendizagem de línguas estrangeiras no ensino superior. Porto: FLUP, 2019, pp. 394-413 DOI: https://doi.org/10.21747/9789898969217/paraa22

to conceptualising second language acquisition which would encompass other dimensions involved in the processes of learning (Atkinson, 2011; Block, 2003). Today, for instance, emotions have become the object of much investigation in the field as the affective characterises one of these interrelated dimensions. Diverse methods, approaches, and perspectives have been employed to explore the role of emotions in informing and influencing second-language-learning experiences. Of course, considering the significance and complexity of the relationship between emotions and second language learning, it should be of no surprise that research on this topic continues to grow quickly and to pose new challenges to the field.

A number of SLA researchers now consider the affective to be an integral dimension of learning, and to influence the second-language-learning experiences of learners in very dynamic ways. An emotion such as anxiety, the focus of much early research (e.g. Horwitz, Horwitz, \& Cope, 1986; Krashen, 1985), can play both positive and negative roles in influencing the outcomes of second-language-learning experiences; yet, it does not affect every learner in the same manner or to the same extent. Still, early insights into the ways in which emotions might affect second language learning stemmed exclusively from the classroom context, and reflected cognitive-focused perspectives of SLA without meaningful reference to the social dimension of learning (Phillips, 1991; Swain, 2013; Young, 1990).

Inevitably, as emotions influence the second-language-learning experience, they also impact the development and enactment of learners' identities in the second language, both in and outside the language classroom (Morita, 2004). Identity development in a second language is in itself complex, evoking and influenced by the affective in addition to various other aspects that help constitute one's identity, such as race, ethnicity, gender, age, and sexuality. However, in the SLA literature, the embodied experience has referred to the interplay between cognition and psychological feelings, consequently rendering the contribution of corporeal (physical) sensations to the experience noticeably less explored. Moreover, as Kinginger (2013) has argued, insights into identity-related experiences in the second language continue to be overwhelmingly dominated by research concerning English as either the second or foreign language. 
TAVARES, Vander - The inter-relatedness of emotion, language learning and identity. Para lá da tarefa: implicar os estudantes na aprendizagem de línguas estrangeiras no ensino superior. Porto: FLUP, 2019, pp. 394-413 DOI: https://doi.org/10.21747/9789898969217/paraa22

\section{1 - This study}

This study aims to contribute to SLA research by expanding our knowledge of the relationship between emotions, foreign language learning, and identity. One Canadian adult learner of Portuguese describes her foreign-language-learning-related experiences with a focus on emotions. In doing so, she reveals her perceptions of the ways in which emotions and corporeal sensations (e.g. gustation, audition, sight) played a role in influencing the outcomes of her foreign language learning and foreign language identityrelated experiences. To better analyse and discuss the findings, this study draws upon two relevant concepts of Vygotskyan sociocultural theory (SCT): perezhivanie and regulation, and on the framework of construals of the self for understanding emotional experiences as culturally influenced. This study is guided by the following questions: (1) what role does emotion play in informing and shaping the learner's foreign language learning experiences? and (2) in what ways do emotions and corporeal sensations contribute to learners' identity-related experiences in the foreign language?

\section{2 - Theoretical frameworks}

\section{1 - Emotions within language learning through sociocultural theory}

From a Vygotskyan SCT stance, an individual's development of their cognitive functions occurs through social interactions and with the assistance of culturallyproduced artefacts, whether material or symbolic (Swain, Kinnear, \& Steinman, 2015). In this theory, language is considered one of many culturally-constructed symbolic artefacts which mediate mental functions. Yet, 'language' (i.e. speech) is also a mental function in itself. In the context of foreign language learning, the acquisition of language - the cognitive processing of speech - unfolds through social interaction and is symbolically mediated through one or more cultural linguistic codes (e.g. through one's dominant or target language).

Many concepts stemming from sociocultural theory have lent themselves to hypothesising and challenging SLA research. Considering the focus of this study, two of these concepts have been applied: first, the concept of regulation. Briefly speaking, in SCT, developmental and behavioural experiences are understood to be regulated and to occur in stages (Lantolf, Thorne, \& Poehner, 2015). In the first stage - objectregulation - objects regulate mental functioning, as in using wooden blocks to help mentally process calculation. In the second stage - other-regulation - mental functioning depends on the assistance of individuals, normally more skilled than the learner him- or 
TAVARES, Vander - The inter-relatedness of emotion, language learning and identity. Para lá da tarefa: implicar os estudantes na aprendizagem de línguas estrangeiras no ensino superior. Porto: FLUP, 2019, pp. 394-413 DOI: https://doi.org/10.21747/9789898969217/paraa22

herself. As development progresses over time, an individual reaches the last stage: selfregulation. In this stage, the individual is able to regulate an experience by him- or herself. Although normally presented in sequential stages, depending on the complexity of a task or experience, learners may not move through this continuum linearly. With this understanding, regulation is employed to analyse learners' perceptions of their foreign language learning and identity-related experiences.

The second relevant concept is perezhivanie (plural: perezhivaniya). Because of the complex meaning behind this Russian term, no direct equivalent term in English has been proposed, hence the continuous use of the term in its original language. According to Blunden's 'translation' (2016), "perezhivaniya have a beginning, a middle, and an end; they are events, episodes, activities, happenings or experiences in which people are active participants" (p. 275). Each perezhivanie is an inter-related unit in one's life whether positive or negative, big or small - which has contributed in some significant and memorable manner to the individual's personality development and life history. What is particular to this term is that in addition to it being a lived emotional experience, it also encompasses the working-through of this experience. To exemplify, losing a loved one is a perezhivanie, since both the loss and the working-through of that loss (e.g. grieving) constitute two essential, inter-connected sides of the same experience. Therefore, the working-through of some perezhivaniya may take years to conclude, and to some thinkers, it may also require the assistance of a more experienced other, such a therapist, to reach its conclusion. Blunden (2016) explained that many scholars regard perezhivaniya as "a unity of affect and intellect" (p. 278) because one's cognitive development directly affects his or her emotional development, and vice-versa, as the product of each concluded experience. Blunden (2016) explained the significance of memorable episodes to one's sense of self in light of this theory:

Perezhivaniya are the units or chapters of one's autobiography, the episodes that stand out in the memory from the background of one's life, and having been worked over by you and told and retold (to yourself or others), and "coded" in language and images, become meaningful. Together perezhivaniya form the basis of who you are: not just what happened to you, but what you did, what you made of your life, in the context of the life-projects to which you were committed and that made the event life-changing and emotion-charged, how you worked over them and gave them meaning (p. 278). 
TAVARES, Vander - The inter-relatedness of emotion, language learning and identity. Para lá da tarefa: implicar os estudantes na aprendizagem de línguas estrangeiras no ensino superior. Porto: FLUP, 2019, pp. 394-413 DOI: https://doi.org/10.21747/9789898969217/paraa22

\section{2 - Construals of the self}

The expression and perception of emotions by different cultural groups has been explored in interdisciplinary approaches by scholars in psychology, anthropology, and linguistics (Berry, 2002; Nisbett, 2004; Pavlenko, 2005; Samovar et al., 2012). The seminal work of Markus and Kitayama (1991) has illuminated our understanding of the systematic ways in which cultural groups express and perceive emotions by focusing on construals of the self. By this light, various aspects of cognition and emotion are viewed as partially mechanised in response to how individuals conceptualise the self, the other, and the relationship between the two in different societies around the world. The scholars drew on American and Japanese societies to broadly exemplify two conceptualisations of the self: the independent and the interdependent.

For the independent construal of the self - more commonly labelled "individualistic" - the inner aspects of the self are seen as detached from or unaligned with those of others, and are therefore representative of interests of the independent individual alone. These inner aspects (e.g. individual desires, preferences, abilities) function as regulators of the behaviour of the independent self. On the other hand, for the interdependent construal of the self - also referred to as "collectivist" - one's inner aspects intersect with those of others. In this sense, the behaviours and attitudes of the interdependent self primarily reflect those formed by and within the self-and-other relationship, thus fostering a more meaningful sense of the self for the individual when the self is a member of a larger, inter-connected social unit; this does not, however, signify the interdependent individual lacks an individually unique set of inner aspects of the self.

Markus and Kitayama (1991) then suggest that the expression of emotions is performed in relation to the culturally-regulated position of the self within a particular social interaction. In such contexts, private feelings may be overtly expressed, or backgrounded for the sake of a harmonious interaction: "For those with independent selves, emotional expressions may literally "express" or reveal the inner feelings such as anger, sadness, and fear. For those with interdependent selves, however, an emotional expression may be more often regarded as a public instrumental action that may or may not be related directly to the inner feelings" (p. 236).

\section{3 - Emotions and foreign language learning}

Learning a foreign language is a very emotional experience. Whether it is the journey of learning through instruction - situated, for example, within the classroom - or the experience of naturalistically using the foreign language in target contexts, it is not 
TAVARES, Vander - The inter-relatedness of emotion, language learning and identity. Para lá da tarefa: implicar os estudantes na aprendizagem de línguas estrangeiras no ensino superior. Porto: FLUP, 2019, pp. 394-413 DOI: https://doi.org/10.21747/9789898969217/paraa22

uncommon that both processes should evoke a wide range of emotions in the learner. In turn, these emotional experiences can influence the language learning experience positively or negatively. However, contrary to the belief that negative emotions and emotional experiences such as frustration and embarrassment necessarily prevent language acquisition or de-motivate a learner to continue learning, these experiences may actually result in productive and successful learning outcomes at times (Imai, 2010; Santiago, 1993).

Indeed, the famous case study of Schmidt learning Portuguese in Brazil and documenting his daily learning experiences with classmates and interactions with local Brazilians in his journal reveals a diverse range of emotions that characterised his overall experience. These encompassed frustration, eagerness, embarrassment, satisfaction, annoyance, exhaustion, euphoria, discouragement, stimulation, gladness, surprise, nervousness, and a sense of feeling lost and strange (Schmidt \& Frota, 1986). Schmidt reported that his feeling of frustration - which resulted from his continuous inability to proficiently carry a casual conversation in Portuguese early on - motivated him to further invest in learning the language in and outside the classroom, even though there might not have been a realistic need for him to do so considering most of his colleagues spoke fluent English at the university in Rio, his site of work.

From a Vygotskyan sociocultural perspective, affect and cognition form an inextricable relationship (Vygotsky, 2000). In the context of foreign language learning, thinking and feeling can together enhance the process and the outcome of learning (del Río \& Álvarez, 2002; Swain, Kinnear \& Steinman, 2015). After feeling frustrated, Schmidt felt eager to study and learn more. He reported that, after days into his beginner's course, he would answer the instructor's questions with more advanced vocabulary and syntax for the class level by cause of his self-teaching, since his goal was to be able to engage in productive conversational interactions with local Brazilians as fast as possible. Through a sociocultural analytical lens, the feeling of eagerness and the emotional experience of frustration may represent the impetus for his cognitive-related language learning success. Other emotionally negative experiences can be found extensively in his journal entries; however, these only seemed to inspire him to further his learning.

On several occasions, additionally, Schmidt reported relying on the affective support of local Brazilians in the form of patience and encouragement for his development of comprehension and oral conversational skills in Portuguese. This affective support played a role in fostering a sense of self-confidence and fluency in him over time. In other instances, the cognitive control over speech on the part of local Brazilians, as in 
TAVARES, Vander - The inter-relatedness of emotion, language learning and identity. Para lá da tarefa: implicar os estudantes na aprendizagem de línguas estrangeiras no ensino superior. Porto: FLUP, 2019, pp. 394-413 DOI: https://doi.org/10.21747/9789898969217/paraa22

deliberatively slowing down the rate of speech, made Schmidt fee/ welcomed, included, and supported. When he could not keep up with the level of discourse among intellectual Brazilians, he would depend on an interlocutor to negotiate him back into the conversation. Paying attention to the needs of others may be therefore construed as an inter-personal dimension of affective-cognitive relationships in SLA-related experiences (Mahn \& John-Steiner, 2002).

Analogous to the ways by which emotions can provoke changes to learning processes and outcomes in the foreign-language (learning) context, they can also impact the learner's identity enactment in the dominant language (L1) and identity development in the foreign language (L2). Emotions and emotional experiences are relational to the learner's socially-constructed, foreign-language-based identity (or identities) (e.g. feeling like a competent, fluent speaker of the foreign language in light of recognition, praise, and encouragement by others), but also to the performance of an identity (or identities) the speaker has socioculturally constructed in and through the dominant language.

Everett's (2008) detailed documentation of his linguistic fieldwork with the Amazon's indigenous Pirahã community illustrates one of the possible ways in which emotions, foreign language learning, and identity may intersect and, in this particular instance, clash. Everett experienced internal conflict and uneasiness throughout his journey of learning the indigenous Pirahã language not because the language was a completely new code to learn, with new grammatical and phonological rules to be mastered. Rather, these emotional experiences originated primarily from his encounter with new indigenous social and cultural values - embedded in and reflected through the Pirahã sociolinguistic practices - which led him to challenge his own personal values. As a result, Everett questioned religious, social, and cultural aspects of his dominant identity that he had acquired from growing up in an English-speaking society.

The complexity of the relationship between emotions and the construction of foreign language identities has been explored extensively in the SLA research. Relevant to this study is the recognition that a learner's identity is neither singular nor fixed. Instead, it is dynamic; constituted of multiple roles; contextually-shaped; socially, linguistically and collaboratively constructed; and oftentimes, ascribed to the learner by others, although they can also be claimed by the learners themselves (Duff, 2012; Edwards, 1985; Kinginger, 2013; Norton, 2010; You, 2016). Learners' membership into foreign language social groups may also be interfered with by issues of race, gender, sexuality, age, and ethnicity. To capture the complex and multiple constituents of a learner's identity, Pavlenko and Blackledge (2004) have defined it as "a dynamic and shifting nexus of 
TAVARES, Vander - The inter-relatedness of emotion, language learning and identity.

Para lá da tarefa: implicar os estudantes na aprendizagem de línguas estrangeiras no ensino superior. Porto: FLUP, 2019, pp. 394-413 DOI: https://doi.org/10.21747/9789898969217/paraa22

multiple subject positions, or identity options, such as mother, accountant, heterosexual, or Latina" (p. 35).

Tavares (2016) analysed a number of studies concerning the linguistic experiences of speakers of English as a second language in conversational peer interactions in English-medium higher education contexts. On the subject of foreign language identity, Tavares found that the degree of support offered by interlocutors in the academic setting contributed critically to how learners perceived themselves in and outside the classroom: their self-perceptions fluctuated contextually between more or less competent speakers of English. Furthermore, threats to the identity in the foreign language initiated by peers provoked a range of negative psychological and psychiatric emotions in the learner, varying across depression, anxiety, isolation, shyness, embarrassment, and feelings of exclusion. In this light, as learners' emotions fluctuate, so do their perceptions of their own identities, and vice-versa. Findings such as these reinforce our understanding that foreign language identities are not static, and that their enactment can turn into a very visceral experience of legitimacy and positionality for the learner.

\section{4 - Methodology}

This study sought to explore the inter-relatedness of emotions, foreign language learning, and identity by drawing on the experiences of an adult learner of Portuguese as a foreign language in Toronto, Canada. Marta (pseudonym), the study's participant, was a multilingual learner whose linguistic repertoire included knowledge of English, Spanish, and Russian. After immigrating to Canada in her late 20s in the early 2000s, Marta met her soon-to-be husband, a native of Portugal who had also immigrated to Canada as an adult. Marta grew up speaking Russian as an L1, and began learning English as a foreign language in middle school. Additionally, she studied French for three years in elementary school, and Spanish for one year in high school.

At the time of the study, Marta was in her late 30s and learning beginner's Portuguese at a post-secondary institution in Toronto. However, prior to the language course in the fall of 2016, Marta had spent two years self-teaching Portuguese through lessons in textbooks and on the internet. At home, Marta and her husband spoke primarily English. When practicing her Portuguese at home, Marta relied on her husband for feedback, but as she progressed in the language through self-teaching, she decided to enroll in the course to gain more specialised feedback. Other interactions which afforded her additional exposure to the language consisted of annual trips to Portugal with her 
TAVARES, Vander - The inter-relatedness of emotion, language learning and identity.

Para lá da tarefa: implicar os estudantes na aprendizagem de línguas estrangeiras no ensino superior. Porto: FLUP, 2019, pp. 394-413 DOI: https://doi.org/10.21747/9789898969217/paraa22

husband to visit his side of the family. In addition to her self-teaching, Marta also reported drawing on her knowledge of Spanish to make sense of unfamiliar content in Portuguese.

Two semi-structured interviews (Richards, 2009) were conducted to learn about the role of emotions in Marta's foreign language learning experiences. The interviews lasted 40 minutes on average and were conducted in the winter of 2017, two months after the end of her language course. Data analysis was completed through a three-step process: transcribing, identifying, and categorising. Identifying and categorising the themes consisted first of what Richards (2009) described as "scribbling down in the margin the topics covered in the interview. At this stage it does not matter how many or how specific these [topics] are" (p. 192). A number of topics emerged from the interviews, including family, marriage, languages, schooling, travelling, and goals. The topics were then grouped into the broader categories of emotions, language learning, and identity, which Kelchtermans (1993) referred to as the 'vertical analysis.'

\section{5 - Findings}

\section{1 - The influence of family in formal foreign language learning}

Several may contribute to an individual's decision to enroll in classroom-based foreign language instruction. These factors may include the need to know the language for employment or academics, the desire to pursue a hobby, or the push to learn based on family relations, to cite a few examples. This categorical section describes specifically the role which family relations played in motivating Marta to learn her respective foreign language in an instructed learning setting.

As mentioned previously, Marta was married to a Portuguese national who resided in Canada. Her motivation to learn Portuguese as a foreign language stemmed from the desire to develop closer family relations:

My husband travels once a year to Portugal for about a month to see his brothers and sisters. His family members don't speak English. I knew that eventually I would be visiting them and was hoping that it would be [a] yearly thing. I wanted to learn Portuguese so I could communicate with them and that's the reason I took Portuguese. (Interview 1)

Marta and her husband spoke to each other in English, and to a lesser extent, Portuguese, especially at home. However, Marta's preoccupation was with communicating with her in-laws and other extended family members who lived in Portugal and only spoke Portuguese. She considered the language difference a major 
TAVARES, Vander - The inter-relatedness of emotion, language learning and identity. Para lá da tarefa: implicar os estudantes na aprendizagem de línguas estrangeiras no ensino superior. Porto: FLUP, 2019, pp. 394-413 DOI: https://doi.org/10.21747/9789898969217/paraa22

obstacle to her communication with and integration into the family. When considering the frequency in which she and her husband travelled to Portugal for family visits, Marta decided that investing in classroom-based learning would be beneficial in strengthening her language skills and, as a consequence, also her family ties.

Language learning for Marta may be better seen from a perspective of heritage languages (Valdés, 2001) as she developed a personal connection, through family, with a language not normally taught in Canadian schools. Typically, these languages are spoken in the home fluently by the parents or grandparents, while the children might possess different proficiency levels gained from infrequent speaking with or listening to the heritage language speakers. Marta's case was differentiated by the fact her primary influence was not only her husband, but also, and perhaps of equal or more weight, his family living in Portugal. For her, the early family-focused interactions in the language, which she could only minimally understand, led her to pursue formal classes in the language in order to improve her communicative skills.

\section{2 - Emotional experiences regulate perceptions of foreign-language- learning experiences and respective identities, and vice-versa}

In the past, Marta's experiences in Portuguese were regulated by her husband translating and including her in conversations with his family members. After finishing her Portuguese language course, Marta reported she could regulate her own interactions more independently. The ability to self-regulate resulted in two positive experiences for Marta: first, she was better able to feel like a part of the family, in the roles of sister- or daughter-in-law; and second, the experience evoked feelings of happiness, inclusion, pleasure, and enjoyment. Consequently, these memorable family-related conversational episodes - or perezhivaniya - had a positive impact on Marta and on her relationship with the language, and have contributed to the construction of her (family member) identity in the foreign language. Marta described her experience speaking Portuguese with her new family members in a positive light:

When I visited Portugal in January this year, to my surprise I found out that I understood my new family members approximately about 70 to $80 \%$. It made me very happy, it was so easy to communicate to them, they felt so comfortable being around me... they did not treat me as a foreigner and spoke fluently around me all the time. It made my trip so pleasurable for me and for my husband because he did not have to worry about translating to me or feeling bad that I'm being left out of a conversation or feeling bad that I don't understand what they are talking 
TAVARES, Vander - The inter-relatedness of emotion, language learning and identity. Para lá da tarefa: implicar os estudantes na aprendizagem de línguas estrangeiras no ensino superior. Porto: FLUP, 2019, pp. 394-413 DOI: https://doi.org/10.21747/9789898969217/paraa22

about and where he would be forced to translate or include me in [a] conversation. Being able to communicate and to understand made me enjoy being around family. (Interview 1)

Marta explained how the experiencing of important upcoming family-related events in Portugal informed her motivation to continue to learn the language. She mentioned studying the language on a daily basis, even if for brief periods of time, in order to acquire new knowledge or solidify content she had learned previously and considered relevant for conversational interactions. The emotional events (e.g. a baptism and a wedding in the family) in the foreign language are tied to Marta's enactment of her hoped-for (Portuguese) family identity as they afford her an opportunity to use the language to present herself from an identity position she would like others to meet her in while socialising with guests at the events who, like her in-laws, may only speak Portuguese:

In the end of July until the end of that August [2017], for a month my family is planning to visit Portugal this year again. I am motivated to learn how to speak Portuguese more fluently so I can enjoy my time with my family members. There's going to be a baptism of two kids and a church wedding and there are going to be a lot of people that I haven't met before and would like to communicate with. In order to get better I am practising and learning Portuguese on a daily basis. Even if it takes 15 minutes a day to learn a few new words or repeat the words that l've learned before, I know it will give me more confidence to speak and make me understand more. (Interview 2)

One particular family-related experience that has stayed with Marta since its occurrence illustrates an intersection between emotions, foreign language learning, and identity that strengthened both affect and intellect. In this experience, Marta's use of Portuguese in an intimate conversation with her sister-in-law - which in her view she could not easily perform prior to the language lessons - played an important role in fostering a sense of self-reassurance with respect to her skills in the language and her role in the family. She made reference to a meaningful, bonding conversational interaction which included attentive listening, speaking, sympathising, and crying together with her sister-in-law. In addition to the using the language more proficiently, Marta felt closer to her extended family through the experience. In turn, the experience changed her husband's perspectives of her proficiency in the language. Initially, Marta reported he was skeptical of her abilities in Portuguese, but after hearing about the 
TAVARES, Vander - The inter-relatedness of emotion, language learning and identity. Para lá da tarefa: implicar os estudantes na aprendizagem de línguas estrangeiras no ensino superior. Porto: FLUP, 2019, pp. 394-413 DOI: https://doi.org/10.21747/9789898969217/paraa22

experience directly from his sister, who only spoke Portuguese, he felt "amazed" that Marta was able to engage in a conversation in which sensitive topics were discussed and deep emotions were shared.

I asked my sister-in-law to give me a tour of the rest of the house. We left the area where my husband and my brother-in-law were talking and drinking some coffee, and went across the garage to the second floor of the house. My sisterin-law and I had about 20-minute conversation about her daughter-in-law and some other things that happened in her life... We talked, we cried, we talked how life is unfair and how hard it is for her. When we left her house, I spoke to my husband about the conversation I had with his sister. My husband listened and did not see much. The next day, when we went to visit his sister, she talked to him about everything she and I discussed the night before. When we left her house, my husband told me: "I am very amazed, I'm stunned, I can't believe it." When I asked him what he is referring to, he told me that his sister told him everything we talked about the night before. He couldn't believe his ears because she said exactly the same thing that I told him the night before and that made him realize that I understand more that he thought I did. He felt very happy and proud of me and almost not believing that I was able to hold a very deep conversation with the sister and was able to understand... because in his opinion, Portuguese is not an easy language to learn. (Interview 2)

These episodes demonstrate a potential relationship between emotions and motivation. Positive emotional experiences in the foreign language - as in being recognised and accepted in the immediate foreign language community, which in Marta's case was her husband's immediate and extended family, or in experiencing happiness and enjoyment as a result of either positive learning outcomes or successful interactional attempts - motivated Marta to continue to want to learn and speak her target language, as generally found in the SLA literature discussed earlier. As for identity, emotions and emotional experiences regulated the perception of the learner's own identity in the foreign language in proportionate ways. Positive emotions and emotional experiences, such as the one identified above, resulted in positive perceptions, usually of a more competent speaker, and of a more tangibly attainable identity in the family constructed and enacted through the language. 
TAVARES, Vander - The inter-relatedness of emotion, language learning and identity. Para lá da tarefa: implicar os estudantes na aprendizagem de línguas estrangeiras no ensino superior. Porto: FLUP, 2019, pp. 394-413 DOI: https://doi.org/10.21747/9789898969217/paraa22

\section{3 - Corporeal sensations influencing foreign language identity experiences}

This category focuses on the role played by corporeal experiences in the learner's construction and enactment of her foreign language identity. As Marta described her characterisation of her hoped-for foreign language identity, she pointed to direct and subjective experiences in which not only psychological emotions were experienced, as elaborated in the previous section, but also those of a corporeal nature. Marta's perception concerning some of the traits characteristic of an identity of Portuguese language speakers was also shaped initially by a subjective, corporeal experience. This time, it originated from how the language sounded to her: "beautiful, poetic, smooth, and sexy."

When I first heard my husband speak to his friend in Portuguese, I liked the language and the way it sounded. I like Romance languages and the way they sound. I studied French in elementary school for four years and I studied Spanish in high school for one year. Portuguese language has some similar words as the Spanish language, which is in my opinion the sexiest language on earth. Before I started studying Portuguese and understanding it, I was able to sit in a room with people who speak Portuguese and even though I did not understand a word, it did not bother me because [of] the way [the] Portuguese language sounds to an ear. It's a beautiful and poetic language. It sounds smooth and sexy. (Interview 2)

In fact, it is not uncommon to find such associations to romance languages and romance language speakers (Karandashev, 2015; Pérez, Fiol, Guzmán, Palmer \& Baudes, 2008). For example, in their study with high school students, Williams, Burden and Lanvers (2002) found that female learners were interested in learning French because of how it sounded, considering it the language of love; while male learners preferred German because they considered German to be the language of logic and to "sound" more masculine. Guttfreund's analysis (1990) of Spanish-English bilinguals' language use revealed affection was expressed significantly more in Spanish than it was in English. Schmidt (Schmidt \& Frota, 1986) reacted to the sound of Portuguese while listening to it on the radio and TV by saying "Portuguese is certainly a beautiful language" (p. 243). 
TAVARES, Vander - The inter-relatedness of emotion, language learning and identity. Para lá da tarefa: implicar os estudantes na aprendizagem de línguas estrangeiras no ensino superior. Porto: FLUP, 2019, pp. 394-413 DOI: https://doi.org/10.21747/9789898969217/paraa22

When describing her views of Portuguese people, Marta mentioned events in which both the language and the culture were experienced through the emotions and corporeal sensations of gustation and audition:

Portuguese people, in my opinion, are very kind, down-to-earth people, who love family get-togethers and enjoy eating food with family and friends. Since I come from a background that has similar values, that's why it's easy and enjoyable to be around Portuguese people for me. Portuguese culture is rich and filled with long history. It's famous for its medieval castles, museums and ancient church buildings. The music Fado that only exists in Portuguese culture, and Samba [are] different in a good way. (Interview 2)

Marta's emotional transition into the new family's cultural dynamics was unproblematic and rather "easy and enjoyable" because she did not seem to experience any conflict to her (interdependent) sense of self already in place. In her words, coming from a background with "similar [social and cultural] values" allowed her to transition smoothly into another culturally-mediated environment where she considered emotional experiences to be familiar and enjoyable. The unproblematic cultural alignment between her two cultures-that is, between her home and the Portuguese cultures-allowed her to focus on the development and improvement of other aspects of her foreign language experience, such as on the use of language itself and the enactment of her hoped-for identity.

Corporeal sensations were present in most of Marta's recollections of her foreignlanguage-learning-related experiences. Whether the mentioning of these associations was produced unconsciously or otherwise, Marta did refer to experiencing events in the foreign language through corporeal sensations to a noticeable extent: primarily gustatory, and often around food-sharing moments with her family in Portugal. Indeed, cross-cultural experiences of food sharing or preparing can provide unique insights into the ways identities of cultural groups are individually and collectively constructed (Almerico, 2014; Hayes-Conroy, 2010; Hayes-Conroy, 2014; Kittler, Sucher \& Nelms, 2012; Sutton, 2001).

Therefore, corporeal sensations not only helped characterise the foreign language learning experience, but also extended into identity development and enactment in the foreign language. Perceptions of an enacted identity in the foreign language involved a direct attention to the linguistic-for instance, how native speakers of Portuguese sounded or the correct sentence structure-and to the emotional, as in how Marta 
TAVARES, Vander - The inter-relatedness of emotion, language learning and identity. Para lá da tarefa: implicar os estudantes na aprendizagem de línguas estrangeiras no ensino superior. Porto: FLUP, 2019, pp. 394-413 DOI: https://doi.org/10.21747/9789898969217/paraa22

subjectively characterised the foreign language and culture (e.g. "kind and down-to-earth people"). Yet, identity experiences involved also an awareness of corporeal sensations: the sound of the local music, the taste of the typical food, the temperature of the local weather-corporeal sensations that, to the learner, represented experiences characteristic of the target identity. In this light, perceptions of foreign language identities may then involve an attention to corporeal sensations because these perceptions are imagined and constructed through these sensations. Lastly, Marta's experiences point to a direct connection between her past, memorable experiences - perezhivaniya - and her foreign language identity perceptions. Therefore, to more adequately understand how foreign language learners conceptualise broader cultural identities and who they hope to become, it may be useful to consider the past emotional and corporeal experiences in which they participated in the foreign language.

\section{6 - Conclusion}

This study sought to explore the influence of emotions in the foreign-languagelearning and identity experiences of one Canadian adult learner of Portuguese as a foreign language. A construals-of-the-self framework and sociocultural theory's concepts of regulation and perezhivanie were employed to understand the learner's cross-cultural and emotional language-focused experiences. In addition to the role of psychological emotions, this study also considered the role of corporeal sensations: in, on, or through the body.

The experiences of the learner in this study support a complex theory of SLA characterised by interconnected dimensions, which include the affective. As Fleer and colleagues (2017) have noted, Vygotskyan sociocultural theory has always approached cognitive and affective processes as inseparable, even if this inextricable relationship was left unsophisticatedly explored in the early days of SCT theory. In the accounts of the learner's experiences presented in this paper, emotions and emotional experiences informed the course of the language learning experience in cyclical and corresponding ways: positive learning experiences resulted in positive emotions, and the opposite was also true. This finding is consistent with the literature reviewed early on in this paper.

With specific reference to identity in the foreign language, the learner's experiences help strengthen the theoretical foundation upon which this study was built: that identity is a complex, multifaceted, and dynamic nexus for foreign language learners. Experiences within and around this identity nexus are informed by distinct factors - in this paper emotions are the focus factor. . A reading of the learner's experiences also 
TAVARES, Vander - The inter-relatedness of emotion, language learning and identity. Para lá da tarefa: implicar os estudantes na aprendizagem de línguas estrangeiras no ensino superior. Porto: FLUP, 2019, pp. 394-413 DOI: https://doi.org/10.21747/9789898969217/paraa22

suggests that, despite her linguistic progress emotions and emotional experiences seemed to regulate her perception of one aspect that may for some be an indispensable part of their identity in the foreign language - that of linguistic competency - rather than their actual competency (Swain et al, 2015). However, when thinking of the influence of emotions on identity-related experiences, it is essential to consider also the role of corporeal sensations as emotions go beyond the psychological but may seem less subjective given the discursive ways in which emotions are "labelled" in relation to the self: we feel psychological emotions (e.g. tiredness, embarrassment, anxiety, confidence, joy), but do not reference corporeal sensations in the same way: the music is loud, the sun is hot, the food is sour, and so on; even though corporeal sensations are also felt and experienced in, on, and through the body - gustation, warm weather, and digestion to cite a few.

Therefore, corporeal sensations may also be present, implicitly or explicitly, in learners' foreign-language-identity-related experiences. They may be present in two temporal instances: the present - corporeal experiences learners experience while learning a language in the present time which have direct influence on their conceptualisations of target language identities - or the (distant) past, which may then demonstrate the existence of a connection between perezhivaniya and (imagined or hoped-for) foreign language identities: past experiences influence identity experiences, conceptualisations, and enactment. In this sense, corporeal sensations, in addition to psychological ones, also co-constitute the basis for perezhivaniya. A past and meaningful emotional experience - a perezhivanie - such as an intense sensation in the foreign language (environment), is also experienced and constructed through corporeal sensations, even if felt but unacknowledged, unlike the way psychological sensations may be more frequently expressed (or linguistically performed) by different cultural groups (see Bamberg, 1997; Markus \& Kitayama, 1991, for more discussion).

This study is based on the perceptions of the learner's on the relationship between emotions, foreign language learning, and identity-related experiences, and did not examine other factors that might have directly influenced her experiences, such as socioeconomic status, ethnicity, and knowledge of other languages in close relation to her respective foreign language of study. Future research can explore these and other aspects. Finally, the importance of continuing to include less traditional or under-explored dimensions of learning in SLA research, such as the affective, should not be underestimated, as these contribute to the development of a more holistic understanding and representation of the foreign language learning and identity experiences for learners. 
TAVARES, Vander - The inter-relatedness of emotion, language learning and identity. Para lá da tarefa: implicar os estudantes na aprendizagem de línguas estrangeiras no ensino superior. Porto: FLUP, 2019, pp. 394-413 DOI: https://doi.org/10.21747/9789898969217/paraa22

\section{References}

Almerico, G. M. (2014). Food and identity: Food studies, cultural, and personal identity. Journal of International Business and Cultural Studies, 8.

Atkinson, D. (Ed.). (2011). Alternative approaches to second language acquisition. New York, NY: Routledge.

Bamberg, M. (1997). Emotion talk(s): The role of perspective in the construction of emotions. S. Niemeier \& R. Dirven (Eds.), The language of emotions: Conceptualization, expression, and theoretical foundation (209-225). Amsterdam: John Benjamins.

Berry, J. W. (2002). Cross-cultural psychology: Research and applications. Cambridge, UK: Cambridge University Press.

Block, D. (2003). The social turn in second language acquisition. Edinburgh, Scotland: University of Edinburgh Press.

Blunden, A. (2016). Translating perezhivanie into English. Mind, Culture, and Activity, 23 (4), 274-283.

del Río, P., \& Álvarez, A. (2002). From activity to directivity: The question of involvement in education. G. Wells \& G. Claxton (Eds.), Learning for life in the $21^{\text {st }}$ century (59-72). Oxford: Blackwell.

Duff, P. (2012). Identity, agency, and second language acquisition. S. M. Gass \& A. Mackey (Eds.), The Routledge handbook of second language acquisition (410-426). New York, NY: Routledge.

Edwards, J. (1985). Language, society, and identity. Oxford: Blackwell.

Everret, D. (2008). Don't sleep, there are snakes: Life and language in the Amazonian jungle. New York, NY: Vintage Books.

Fleer, M., González Rey, F., \& Veresov, N. (2017). Perezhivanie, emotions and subjectivity: Setting the stage. M. Fleer, R. F. González, N. \& Veresov (Eds.), Emotions and subjectivity: Advancing Vygotsky's legacy, (1-15). Singapore: Springer.

Guttfreund, D. G. (1990). Effects of language usage on the emotional experience of Spanish-English and English-Spanish bilinguals. Journal of Consulting and Clinical Psychology, 58 (5), 604-607.

Hayes-Conroy, A. (2010). Feeling slow food: Visceral fieldwork and empathetic research relations in the alternative food movement. Geoforum, 41, 734-742.

Hayes-Conroy, J. (2014). Savoring alternative food: School gardens, healthy eating and visceral difference. New York: Routledge. 
TAVARES, Vander - The inter-relatedness of emotion, language learning and identity. Para lá da tarefa: implicar os estudantes na aprendizagem de línguas estrangeiras no ensino superior. Porto: FLUP, 2019, pp. 394-413 DOI: https://doi.org/10.21747/9789898969217/paraa22

Horwitz, E. K., Horwitz, M. B., \& Cope, J. (1986). Foreign language classroom anxiety. The Modern Language Journal, 70 (2), 125-132.

Imai, Y. (2010). Emotions in SLA: New insights from collaborative learning for an EFL classroom. The Modern Language Journal, 94 (2), 278-292.

Karandashev, V. (2015). A cultural perspective on romantic love. Online Readings in Psychology and Culture, 5 (4), 3-21.

Kelchtermans, G. (1993). Getting the story, understanding the lives: From career stories to teachers' professional development. Teaching and Teacher Education, 9 (56), 443-456.

Kinginger, C. (2013). Identity and language learning in study abroad. Foreign Language Annals, 46, 339-358.

Kittler, P. G., Sucher, K. P., \& Nelms, M. N. (2012). Food and culture (6th ed.). Belmont, CA: Wadsworth.

Krashen, S. (1985). The input hypothesis: Issues and implications. New York: Longman.

Lantolf, J., Thorne, S. L., \& Poehner, M. (2015). Sociocultural theory and second language development. B. van Patten \& J. Williams (Eds.), Theories in second language acquisition (207-226). New York: Routledge

Mahn, H., \& John-Steiner, V. (2002). The gift of confidence: A Vygotskyan view of emotions. In G. Wells \& G. Claxton (Eds.), Learning for life in the $21^{\text {st }}$ century (46-98). Oxford: Blackwell.

Markus, H. R. \& Kitayama, S. (1991). Culture and the self: Implications for cognition, emotion, and motivation. Psychological Review, 98 (2), 224.

Morita, N. (2004). Negotiating participation and identity in second language academic communities. TESOL Quarterly, 38 (4), 573-603.

Myles, F. (2013). Theoretical approaches. J. Herschensohn \& M. Young-Scholten (Eds.), The Cambridge handbook of second language acquisition (46-70). Cambridge: Cambridge University Press.

Nisbett, R. (2004). The geography of thought: How Asians and Westerners think differently... and why. New York, NY: Simon and Schuster.

Norton, B. (2010). Language and identity. N. Hornberger and S. McKay (Eds.), Sociolinguistics and language education (349-369). Bristol: Multilingual Matters.

Pavlenko, A. (2005). Emotions and multilingualism. Cambridge, MA: Cambridge University Press. 
TAVARES, Vander - The inter-relatedness of emotion, language learning and identity. Para lá da tarefa: implicar os estudantes na aprendizagem de línguas estrangeiras no ensino superior. Porto: FLUP, 2019, pp. 394-413 DOI: https://doi.org/10.21747/9789898969217/paraa22

Pavlenko, A. \& Blackledge, A. (2004). Negotiation of identities in multilingual contexts. Clevedon, UK: Multilingual Matters.

Pérez, V. A. F., Fiol, E. B., Guzmán, C. P., Palmer, M. C. R., \& Baudes, E. G. (2008). El concepto de amor en España. Psycothema, 20 (4), 589-594.

Phillips, E. M. (1991). Anxiety and oral competence: Classroom dilemma. The French Review, 65 (1), 1-14.

Richards, K. (2009). Interviews. J. Heigham \& R. Croker (Eds.), Qualitative research in applied linguistics: A practical introduction (182-199). Hampshire, UK: Palgrave MacMillan.

Samovar, L. A., McDaniel, E. R., Porter, R. E. \& Roy, C. S. (2012). Communication between cultures. Belmont, CA: Wadsworth Publishing.

Santiago, E. (1993). When I was Puerto Rican. Toronto, ON: Random House.

Schmidt, R. \& Frota, S. (1986). Developing basic conversational ability in a second language: A case study of an adult learner of Portuguese. R. R. Day (Ed.), Talking to learn: Conversation in second language acquisition (237-326). Rowley, MA: Newbury House.

Sutton, D. (2001). Remembrance of repasts: An anthropology of food and memory. London, UK: Berg.

Swain, M. (2013). The inseparability of cognition and emotion in second language learning. Language Teaching, 46 (2), 195-207.

Swain, M., Kinnear, P. \& Steinman, L. (2015). Sociocultural theory in second language education: An introduction through narratives (vol. 11). Buffalo, NY: Multilingual Matters.

Tavares, V. (2016). The role of peer interaction and second language learning for ESL students in academic contexts: An extended literature review (Unpublished Master's thesis). York University, Toronto, Canada.

Valdés, G. (2001). Heritage language students: Profiles and possibilities. Peyton, J.K., Ranard, D. A. \& McGinnis, S. (Eds.), Heritage Languages in America: Preserving a National Resource (37-80). McHenry, IL: Center for Applied Linguistics.

Vygotsky, L. S. (2000). Thought and language. Cambridge, MA: MIT Press.

Williams, M., Burden, R. \& Lanvers, U. (2002). 'French is the language of love and stuff': Student perceptions of issues related to motivation in learning a foreign language. British Educational Research Journal, 28 (4), 503-528.

You, X. (2016). Cosmopolitan English and transliteracy. Carbondale: Southern Illinois University Press. 
TAVARES, Vander - The inter-relatedness of emotion, language learning and identity. Para lá da tarefa: implicar os estudantes na aprendizagem de línguas estrangeiras no ensino superior. Porto: FLUP, 2019, pp. 394-413 DOI: https://doi.org/10.21747/9789898969217/paraa22

Young, D. J. (1990). An investigation of students' perspectives on anxiety and speaking. Foreign Language Annals, 23 (6), 539-553. 